\title{
Ectoparasite Infestation Prevalence in Cats (Felis Domestica) at the Teaching Animal Hospital of FKH IPB
}

\author{
Tetty Barunawati Siagian a*, Eka Rahmadhani Siregar $b$ \\ $a, b$ Vocational School , Bogor Agricultural University , Bogor, West Java \\ email:a*tetybarunawatisiagian@apps.ipb.ac.id, beka_rahmadhani@apps.ipb.ac.id
}

\begin{tabular}{l}
\hline A R T I C L E I N F O \\
\hline Article history: \\
Received 03 July 2021 \\
Revised 12 Nopember 2021 \\
Accepted 23 December 2021 \\
Available online 31 December \\
2021
\end{tabular}

Keywords:

Ectoparasite

Infestation

Cats

Prevalence

IEEE style in citing this article:

T.B. Siagian and E.R. Siregar, "Prevalence of Ectoparasite Infestation in Cats (Felis domestica) at the Teaching Animal Hospital of FKH IPB," Jurnal Ternak. vol. 12, no. 2, pp. $68-73,2021$.

\begin{abstract}
A B S T R A C T
Cats are animals that are widely kept by the people of Indonesia. Both domesticated and feral cats can be attacked by ectoparasites. Ectoparasites that attacks cats are ticks, mites, fleas and fleas. Ectoparasites can breed well if the sanitation and cleanliness of the cat's cage is not maintained. Data collection was carried out for one month from February $1^{\text {st }}-28^{\text {th }} 2021$.Ectoparasite samples were taken directly from every cat that came to RSHP. The results of the examination showed that 27 cats were positively infected with ectoparasites from 29 cats that had the potential to be infected with ectoparasites. The prevalence of ectoparasite infestation in domestic cats that came to RSHP was $93,1 \%$. A total of 27 cats were infested with ectoparasites consisting of 2 Rhipicephalus sanguineus fleas, 11 Felicola subrostratus fleas, two Sarcoptes scabiei infection mites, 14 infectious mites Otodectes cynotis and infection mites. Ctenocephalides felis as many as 7 tails. One individual cat may be more affected than one type of ectoparasite. The calculation of the prevalence of ectoparasites in cats observed was $93,1 \%$, which consisted of the prevalence of Sarcoptes scabiei infestation 6,89\%, Otodectes cynotis 48,27\%, Ctenocephalides felis 24,13\%, Ripicephalus sanguineus 6,89\% and Felicola subrostratus 37,93\%. The presence of ectoparasites can be minimized by always maintaining cleanliness and routine caring for cats.
\end{abstract}

Jurnal Ternak (Animal Science Journal) Faculty of Animal science - Lamongan Islamic University) with CC BY NC SA license.

\section{Introduction}

Cats are domestication animal. The type of cat that is mostly kept by the community is a local cat (Felis Domestica). Kucing included in Kingdom Animalia, Phylum Chordata, Sub Phylum Vertebrata, Class mammals, Sub Class Theria, Sub Order Fissipedia, Family Felidae, Sub Family Machairodonynae, Genus Fellis Species Fellis Catus [1]. Domesticated cats can be attacked by ectoparasites like ticks, mites, and fleas. Ectoparasites are parasites that live outside the body of their host. Ectoparasites that attack cats can reduce the cat's quality of life. Ectoparasites can breed well if the sanitation and cleanliness of the cat cage is not maintained. Ectoparasite infestation in cats is very high in patients who come to the clinic. Identification and prevalence of ectoparasites in cats needs to be done in order to analyze and recognize the types of ectoparasites in domestic cats in an effort to control, treat and prevent disease transmission to humans. So that owners can provide a good and clean environment, improve maintenance methods and maintain and care for pet cats to avoid disease attacks due to ectoparasite infestations.

Ectoparasites are parasites that live outside of their habitat or on the surface of their host's body [2]. The most common ectoparasites found in cats are ticks, lice, mites and fleas. Ticks is a kind of blood-sucking ticks can be found in pets like dogs and cats. The life cycle of ticks starts from eggs, larvae, 
nymphs and adults. The tick that can infest cats is Rhipicephalus sanguineus [3]. Ticks have 2 suborders, namely Mallopaga (biting lice) and Anoplura (sucking lice). Cat fleas belong to the Mallopaga suborder, Felicola subrostratus. The flea life cycle lasts 1-2 months. Fleas are commonly found on the head, neck and tail of cats [4]. There are various types of mites that attack cats including Notoedres cati, Sarcoptes scabiei (causes scabies), Otodectes cynotis and Demodex sp [5]. Diseases caused infestation mite Sarcoptes scabiei is scabiosis known as scabies. Sarcoptes scabiei lives by making tunnels in the cat's skin and laying eggs in it, so it will not be visible on the surface of the cat's skin [6 ]. Mites that attack cat ears are Otodectes sp. Mite infestations in cats cause intense itching. As a result, appetite and drinking are disturbed and also uncomfortable [7]. Fleas are found in almost all cats that are allowed to live outdoors. The flea that attacks cats is Ctenocephalides felis. Symptoms caused by cats infected with fleas are excessive irritation reactions, hair loss and inflammation [8].

Prevalence is the number of cases of a disease in a population at a time. Environmental change factor 's known to be a risk factor for their ectoparasites. The reproductive cycle of ectoparasites will run optimally in the temperature range of $38^{\circ} \mathrm{C}$. Ectoparasite infection is more common in female cats than in male cats, this is related to the limited movement of female cats, especially when they are pregnant [10]. In addition, care and hygiene of cats that are not paid attention to can lead to the development of ectoparasites [11]. Losses caused by ectoparasites include decreased body weight, decreased production, hair or feather loss, irritation, zoonoses, anemia and death. Another disadvantage is that paralysis (paralysis of the joints) caused by tick bites and dermatitis caused by flea bites [12]. This study aims to describe the prevalence of ectoparasites in cats who come to the Teaching Animal Hospital of FKH IPB.

\section{Method}

Researchers used 29 cats that came to the Teaching Animal Hospital of FKH IPB which is located at Jl. Agatis, Babakan, Kec. Dramaga, Bogor City, West Java 16680, on $01-28$ February 2021 . The method used is the native method as primary data is taken directly from each cat that came to the Rumah Sakit Hewan Pendidikan (RSHP) or Teaching Animal Hospital of FKH IPB . The advantages of the native method are that it is cheap, easy and works fast, but has the disadvantage of being less sensitive to mild infections [13], then the sample is placed on a object glass, dripped with $10 \% \mathrm{KOH}$ and covered with a glass cover and then observed under a microscope with $4 \mathrm{x}$ and 10x magnification. $\mathrm{KOH} 10 \%$ functions as a keratolytic agent, namely to lyse the keratin present in skin and hair scrapings taken [14]. Data were analyzed by calculating the prevalence of ectoparasite infestation in cats using the prevalence formula. Sampling of ectoparasites was carried out based on the ectoparasites to be observed. Collection and inspection samples of the mite Sarcoptes scabiei done directly by the method of skin scrapping or skin scrapings uses scalpel on the skin of infested. Otodectes cynotis samples were taken in the form of ear cerumen. Samples of Ripicephalus sanguineus were taken using $70 \%$ alcohol cotton. Ctenocephalides felis samples were carried out by combing the skin surface in the opposite direction. Felicola subrostratus sample was carried out by taking a sample of hair on the part where the nits were visible. The terminology of prevalence was used to represent the ectoparasite infestation of the examined domestic cats. The prevalence of the ectoparasites in RSHP is calculated by using the following formula [9]:

Prevalence $(\mathrm{P})=\underline{\text { Number of sick individuals at a certain time }}$ $\times 100$

Population at risk at any given time

\section{Results and Discussion}

The examination carried out showed positive results in 27 of the 29 cats who came to the RSHP. An individual cat can be attacked by more than one type of ectoparasite. Table 1 shows the types of ectoparasites that attack cats; 2 Ripicephalus sanguineus warts, 11 Felicola subrostratus, 2 Sarcoptes scabiei infection mites, 14 Otodectes cynotis infection and 7 fleas (Ctenoceephalides felis) infection. 
The flea Ctenocephalides felis is an ectoparasite that acts as a vector of disease and lives on the surface of its host's body [16]. Flea development is influenced by environmental conditions. High temperatures can result in a longer flea breeding time [17]. Flea larvae can survive in temperatures between $4-35^{\circ} \mathrm{C}$. flea Ctenocephalides felis is a type of flea that is often found in dogs and cats [18].

Ripicephalus sanguineus tick is an ectoparasite that is very harmful, especially to pets. The tick that usually attacks cats is Ripicephalus sanguineus [19]. Ticks have incomplete metamorphosis. Female ticks can lay as many as 2000-4000 eggs and will hatch in 17-30 days [20].

The mite Sarcoptes scabiei is an ectoparasite that usually attacks cats and causes scabies. Sarcoptes scabiei lives in the skin by making tunnels in the stratum corneum and continues its life there. Scabies can be transmitted through direct physical contact [21]. Mites Otodectes cynotis is a mite external ear canals that are commonly found in cats, dogs, ferrets and foxes. Otodectes cynotis is the cause of otitis externa in cats, which is $50-84 \%$ [22]. The cycle from egg to adult mite takes about 21 days [23]. Transmission of Otodectes cynotis is by direct contact [24] .

The flea Felicola subrostratus has incomplete metamorphosis. Adult female lice will attach their eggs to the hair of the host. The cycle from egg to adult louse takes 21 days [25]. Transmission can occur directly or indirectly. Transmission is direct by physical contact, while indirectly it can be transmitted through combs and other devices that come into contact with cats with Felicola subrostratus [26] .

Table 1 Results per observations of ectoparasites in cats (Felis Domestica) in RSHP IPB

\begin{tabular}{|c|c|c|c|c|c|}
\hline \multirow[t]{2}{*}{ Cat Name } & \multicolumn{5}{|c|}{ Types of Ectoparasites } \\
\hline & $\begin{array}{c}\text { Ticks (Ripicephalus } \\
\text { sanguineus) }\end{array}$ & $\begin{array}{l}\text { Lice (Felicola } \\
\text { subrostratus) }\end{array}$ & Sarcoptes scabiei & Otodectes cynotis & $\begin{array}{c}\text { Flea (Ctenocephalides } \\
\text { felis) }\end{array}$ \\
\hline Demoy & - & - & - & + & - \\
\hline Jessie & - & - & - & + & + \\
\hline Spekulos & - & - & - & - & + \\
\hline Cimoy & - & + & - & - & - \\
\hline Powpow & + & - & - & - & - \\
\hline Emeng & - & - & + & + & - \\
\hline Ucrit & - & - & + & + & - \\
\hline Mona & - & - & - & - & + \\
\hline Boy & - & - & - & + & + \\
\hline Simba & - & - & - & - & - \\
\hline Blue & - & - & - & + & - \\
\hline Lima & - & + & - & + & - \\
\hline Talia & - & - & - & - & + \\
\hline Boma & + & - & - & + & - \\
\hline Whity oboy & - & + & - & - & - \\
\hline Misya & - & - & - & - & + \\
\hline Shikka & - & - & - & - & + \\
\hline Bibib & - & + & - & - & - \\
\hline Nutella & - & - & - & + & - \\
\hline Dipsi & - & + & - & - & - \\
\hline Yellow & - & + & - & + & - \\
\hline Bomi & - & + & - & - & - \\
\hline Maci & - & + & - & + & - \\
\hline Shiro & - & - & - & + & - \\
\hline Lopis & - & - & - & + & - \\
\hline Moly & - & - & - & - & - \\
\hline Coklat & - & + & - & + & - \\
\hline Menuk & - & + & - & - & - \\
\hline Menik & - & + & - & - & - \\
\hline
\end{tabular}

The calculation of the prevalence of ectoparasites in cats observed was 93,1\%, which consisted of Sarcoptes scabiei $6,89 \%$, Otodectes cynotis $48,27 \%$, Ctenocephalides felis $24,13 \%$, Ripicephalus sanguineus 6,89\% and Felicola subrostratus 37,93\%. [23] said that the prevalence of ectoparasite infestation in Bogor City was 9,5\%. Based on this, it shows that the ectoparasite infestation in Bogor 
Regency (RSHP IPB) is higher than Bogor City. The reason is the lack of public knowledge about the importance of maintaining animal health, cleanliness of cages and the surrounding environment. Another factor is how to maintain cats that are still strayed outdoors and the influence of temperature and humidity in Bogor Regency is higher than that of Bogor City. The effect of temperature and humidity is of course a predisposing factor for the high transmission of ectoparasite infestations and the development of ectoparasites. [27] stated that environmental conditions can affect the survival of ectoparasites. Temperature and high relative humidity that will help the eggs develop improve quality of life cycle ectoparasite.

The type of cat and the conditions of maintenance may influence the susceptibility of cats to ectoparasite attack. Cat race in general is well maintained by the owners and are provided food or drink. In contrast to the local cat, which lives freely in the outdoor even though the owner provides food, so the potential for ectoparasites is greater. Local cats who infected by ectoparasites transmits freely between cats through direct contact [28].

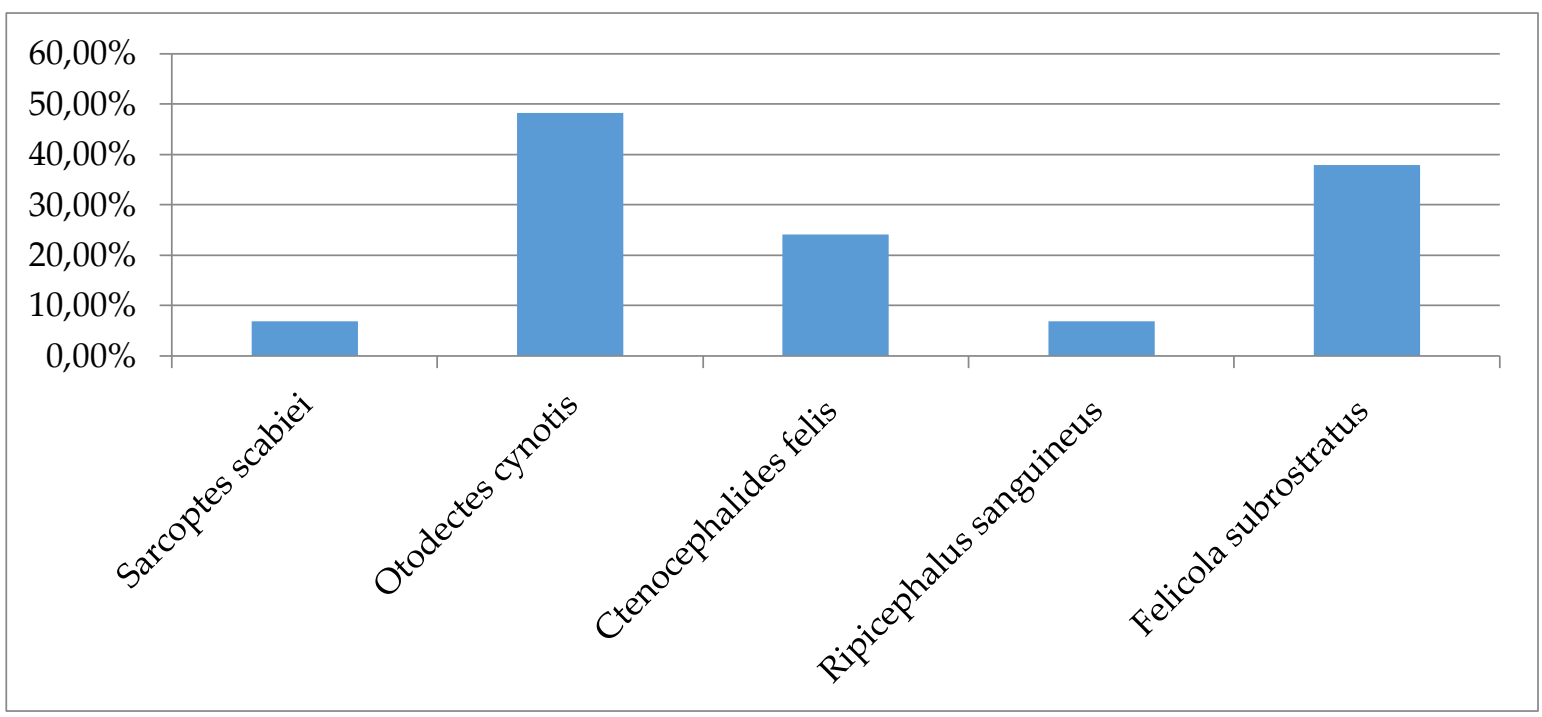

Figure 1 Ectoparasite Infestation Prevalence

Otodectes cynotis infestation is higher than other ectoparasites because the ears are rarely cleaned so that dirt accumulates and causes inflammation and mites to multiply rapidly. Otodectes cynotis is commonly found in cat ears because the temperature and humidity in the cat's ears are factors for the presence of mites. Another factor is the cleanliness of the ears and the surrounding environment that are rarely cleaned, causing mites to easily spread and multiply quickly, so it doesn't take long for mites to produce [29]. Louse infestation Ripicephalus sanguineus lower because $\mathrm{h}$ al in i caused by Ripicephalus sanguineus more common in dogs compared to cats so Ripicephalus commonly called brown dog tick [30]. In addition louse population will increase at warmer temperatures and Ex e mbapan accordingly. A dog's normal body temperature is $37,6-39,4^{\circ} \mathrm{C}$ warmer than a cat's $37-38,4^{\circ} \mathrm{C}$ [31].

The presence of ectoparasites can be minimized by always maintaining cleanliness and routinely caring for cats. Handling ectoparasite carried out by a veterinarian at the Hospital Center of Education FKH IPB is to provide antiparasitic drugs to patients. The antiparasitic drugs given include Revolution ${ }^{\circledR}$ because it contains lambectin and functions as a flea killer, prevents flea eggs and protects cats from breeding fleas (Ctenocephalides felis). Ivermectin ${ }^{\circledR}$ due to Ivermectin, salamectin and the phyretroid group can be used if the main cause is earmites [32] . Mectivar drops because it contains Ivermectin can to clicking a tation infection of lice, fleas, mites, ticks, and worms . Oral drugs given contain antihistamines to reduce itching and antibiotics to prevent secondary infections. In addition, the education given to animal owners is to put cats that are infested in cages, keep away from healthy cats, treat cats in the same house so they don't get infected due to direct contact, and groom cats to keep cats clean. The National Cat Groomers of America recommends that your cat be bathed every 4-6 weeks, to keep the coat from getting tangled and staying healthy . 


\section{Conclusions}

In summary, ectoparasite infestation in cats is very high in patients presenting to the clinic. Identification and prevalence of ectoparasites in cats needs to be done, to study and recognize the types of ectoparasites in domestic cats in an effort to control, treat and prevent disease transmission to humans. Information about ectoparasite infestations is needed by the community as an early awareness of disease and to know the potential of ectoparasites in transmitting disease.

\section{Acknowledgment}

The author would like to thank the Teaching Veterinary Hospital FKH IPB.

\section{References}

[1] Ratmus S. 2000. Sembilan Penyakit Utama Pada Kucing Berdasarkan Frekuensi Kejadian, Tingkat Infeksius, Zoonosa dan Nilai Ekonomi. (Skripsi). Bogor: Fakultas Kedokteran Hewan Institut Pertanian Bogor.

[2] Hadi UK, Soviana S. 2010. Ektoparasit: Pengenalan, Identifikasi dan Pengendaliannya. Bogor (ID): IPB Press.

[3] Dantas TF. 2010. Biology and Ecology of the Brown Dog Tick, Rhipicephalus sanguineus . Jurnal Parasities \& Vectors. 3:26.

[4] Safitri EE. 2013. Ektoparasit yang Menyerang Kucing (Parasitology). Bandung (ID): Vet Medicine.

[5] European Scientific Counsel Companion Animal Parasites [ESCCAP]. 2012. Control of Ectoparasites in Doogs and Cats. Worcestershire (UK): ESCCAP.

[6] Taylor MA, Coop RL, Wall RL. 2007. Veterinary Parasitology, Third Edition. Oxford (UK): Blackwell Publishing.

[7] Taenzler J, Vos DC, Roepke RKA, Hackeroth AR. 2018. Efficacy of fluralaner plus moxidectin againts Otodectes cynotis infestasions in cats. Parasit Vect. 11(595).

[8] Starkey L, Stewart J. 2015. Feline arthropods. Todays Veterinary Practice Journal. 59 - 64.

[9] Dharmojono. 2001. Lima Belas Penyakit Menular dari Binatang ke Manusia. Jakarta (ID): Milenia Populer.

[10] Maharani R, Mahatma R, Titrawani. 2015. Ektoparasit pada Kucing (Felis domestica, Linnaeus 1758) di Kota Pekan Baru. Repository FMIPA [diunduh 2021 mei 21]; https://repository.unri.ac.id/jspui/bitstream/123456789/7825/1/Repository\%20Riri\%20maharan i\%20-\%20Copy.pdf.

[11] Suwandi. 2001. Mengenal Berbagai Penyakit Prasitik pada Ternak. Bogor (ID): Balai Penelitian Ternak.

[12] Regina MP. 2018. Perbandingan pemeriksaan tinja antara metode sedimentasi biasa dan metode sedimentasi Formal Ether dalam Mendeteksi Soil Transmintted Helminth. Jurnal Kedokteran Diponegoro. 7(533): 527 - 529.

[13] Devi LPL, Yaksa YC, Arum YR. 2019. Studi Kasus : Lynxacariasis pada Kucing Persia. Indonesia Medicus Veterinus. 8(2): 169 - 176. DOI : 10.19087/imv.2019.8.2.169.

[14] Purwa BIM, Wahyuni IN, Ati UA. 2018. Identifikasi Ctenocephalides felis pada Kucing Liar (Felis catus) di Daerah Bandar Lor Kota Kediri. Prosiding Seminar Nasional Sains, Teknologi dan Analisis: 73-76.

[15] Sigit SH, Koesharto FX, Hadi UK, Gunandini DJ, Soviana S, Wirawan IA. 2006. Hama pemukiman Indonesia. Sigit $\mathrm{SH}$, Hadi UK, editor. Bogor (ID): Erlangga.

[16] Dobler G, Pfeffer M. 2011. Fleas as parasites of the family Canidae. Parasit Vectors. 4(139):1 - 12. DOI:10.1186/1756-3305-4-139.

[17] Aulanni'am. (2012). Penuntun Praktikum Parasitologi Veteriner. Universitas Brawijaya Malang.

[18] Hary P, Ida T. 2002. Efektivitas Ivermectin dan Fipronil dalam Mengatasi Serangan Caplak. Sain Vet. [diunduh 2021 mei 21]; 20(1): 1-4. Yogyakarta (ID): https://media.neliti.com/media/publications/130716 ID-none.pdf. 
[19] Astyawati T, Wulansari R. 2008. Penanggulangan caplak Ripicephalus sanguineus dengan vaksinasi. Bogor (ID): IPB.

[20] Wardhana AH, Manurung J, Iskandar T. 2006. Skabies: tantangan penyakitzoonosis masa kini dan masa datang. Wartazoa. 16(1): 40-52.

[21] Acar A, Yipel FA. 2016. Factor Related to the Frequency of Cat Ear Mites (Otodectes cynotis). Kafkas. 22(1): 75-78.

[22] Siagian TB, Fikri FH. 2019. Infestasi ektoparasit pada kucing di klinik hewan Kabupaten Bogor. Kendari (ID): SNT2R.

[23] Kartini C, Efendi A, Herlina, Putra MAR. 2017. Catatan Dokter Hewan Pemeriksaan Fisik pada Mata, Telinga, Kardiorespirasi, dan Saluran Pencernaan. Bogor (ID): IPB Press.

[24] Nuraini SD. 2004. Pemberantasan Arthopoda yang Penting dalam Hubungan dengan Kesehatan Masyarakat. Medan (ID). USU Digital Library.

[25] Cahyadi. 2013. Infeksi Kutu pada Hewan (Anjing, Kucing, Sapi, Kuda, Domba, Kambing, Ayam, Kalkun, Merpati dan Itik). Nanggroe Aceh Darussalam (ID): Fakultas Peternakan UNSYIAH.

[26] Jittapalapong S, Sangvaranond A, Inpankaew T, Pinyopanuwat N, Chimnoi W, Kengradomkij C, and Wongnakpet S. 2008. Ectoparasites of Stray Cats in Bangkok Metropolitan Areas, Thailand. Kasetsart J. 42:71-75

[27] Purwa BIM, Wahyuni IN, Ati UA. 2018. Identifikasi Ctenocephalides felis pada Kucing Liar (Felis catus) di Daerah Bandar Lor Kota Kediri. Prosiding Seminar Nasional Sains, Teknologi dan Analisis: 73-76.

[28] Akucewich. 2002. Prevalence of Ectoparasites In A Population of B Feral Cats from North Central Florida During the Summer Vet. 16: 109 (1-2): 129-3.

[29] Levine ND. 1994. Buku Pelajaran Parasitologi Veteriner 8th ed. Yogyakarta (ID): UGM Press.

[30] Widodo S, Sajuthi D, Choliq C, Wijaya A, Wulansari R, Lelana A. 2011. Diagnostik Klinik Hewan Kecil. Bogor (ID): IPB Press.

[31] Da Silva JT, Ferreira LC, Fernandes MM, Sousa LDM, Feitosa TF, Braga FR, Brasil AWDM, Vilela VLR. 2020. Prevalence and clinical aspects of Otodectes cynotis infestation in dogs and cats in the semi-arid region of Parabia. Act Sci. Vet., 48: 17-25

[32] Shehzad MM. 2019. Efficacy of ivermectine, fipronil and their combination again ectoparasites in the Felis catus (cats). Pure and Applied Biology. 8(1). DOI:10.19045/bspab.2019.80097 